\title{
EARNING MANAGEMENT DAN EXPECTED FUTURE EARNING DI BURSA EFEK INDONESIA
}

\section{EARNING MANAGEMENT AND EXPECTED FUTURE EARNING IN INDONESIA STOCK EXCHANGE}

\author{
Taofiq Rachmat ${ }^{* 1}$, Hermanto Siregar ${ }^{* *)}$, dan Tb Nur Ahmad Maulana ${ }^{* * *}$ \\ *) Indonesian Export Credit Agencies \\ Menara Kadin Indonesia Lt 22, Jalan HR Rasuna Said X-5 kav 2-3, Jakarta 12950
}

$\left.{ }^{* *}\right)$ Departemen Ilmu Ekonomi, Fakultas Ekonomi dan Manajemen - Institut Pertanian Bogor Jl. Agatis Kampus IPB Darmaga Gd. Fakultas Ekonomi dan Manajemen W3L2 Darmaga Bogor 16880

${ }^{* * *}$ Sekolah Bisnis, Institut Pertanian Bogor

Jl. Raya Pajajaran, Bogor 16151

\begin{abstract}
The purpose of this study was to applicated M-score to identify earning management in Indonesian corporation. This study also aims to analyst future earning condition from kind of group or sector of corporation which is indicated doing earning management. This study took a sample of 42 corporation using criteria about corporation which is had negatif information. The results of multiple linear regression analysis show that there is evidence that companies with an Earning Management detected earn lower future earnings (a study in Indonesian Stock Exchange Market), the ability of forecast changes in future earnings stems from its ability of predictive power of M-Score (Earning Management Detection Model). There is also, evidence that group companies which had "high attention" from Regulator earn lower expected future earnings. Based on the results of this study, the stake holder are advised to consider M-score to make judgement about financial reports.
\end{abstract}

Keywords: earning management, expected future earning, indonesian stock exchange market, m-score, cross- sectional time-series data

\begin{abstract}
Abstrak: Tujuan dari penelitian ini adalah untuk mengkaji aplikasi M-Score untuk mengidentifikasi earning management pada korporasi di Indonesia. Penelitian ini juga bertujuan mengkaji kondisi expected future earning dari kelompok korporasi yang di informasikan terindikasi melakukan earning management. Penelitian ini mengambil sampel dari 42 korporasi dengan menggunakan kriteria korporasi yang memiliki informasi negatif. Hasil analisis regresi linier berganda menunjukkan terdapat bukti apabila korporasi yang terdeteksi earning management akan mendapatkan expected future earning yang rendah. Kemampuan memprediksi perubahan pada expected future earning didapat dari kemampuan prediksi yang kuat dari M-score (Model untuk mendeteksi adanya earning management). Penelitian menunjukkan bahwa ditemukan konglomerasi usaha yang mendapat pengawasan dari regulator mendapatkan expected future earning yang rendah. Berdasarkan hasil penelitian ini, pemangku kepentingan disarankan menggunakan M-score ketika melakukan penilaian pada laporan keuangan.
\end{abstract}

Kata kunci: earning management, expected future earning, bursa efek indonesia, m-score, data panel

\footnotetext{
${ }^{1}$ Alamat Korespondensi:

Email: taofiqrachmat83@gmail.com
} 


\section{PENDAHULUAN}

Stiglitz (2003) menyatakan " Enron, korporasi tersebut telah menjadi lambang segala kesesatan era 90-an: kerakusan korporasi, skandal akuntansi, hasutan publik, skandal perbankan, deregulasi dan kebijakan pasar bebas semua terangkum jadi satu. Kebangkrutan Enron turut menyeret salah satu Kantor Akuntan Publik yang paling disegani "Arthur Andersen" yang izinnya di cabut dan berakibat kepada lisensi global yang mereka miliki. Kasus Enron meledak saat trik akuntansi untuk menutupi utang dan mengelembungkan pendapatan ini tiba-tiba terbongkar, Enron banyak memakai trik akuntansi yang kian lama kian standar. Trik ini banyak dipakai oleh korporasi di Amerika tahun 90an bahwa trik akuntansi untuk memelintir informasi guna menggenjot harga saham ternyata bisa juga di pakai untuk memperkaya diri sendiri (manajemen) di atas kerugian pemegang saham lainnya. Dalam hal ini Enron adalah yang terbaik".

Salah satu isu utama dalam penelitian dibidang kualitas informasi laporan keuangan (akuntansi), adalah ketentuan dalam regulasi akuntasi GAAP (Generally accepted accounting principles) dimana eksekutif perusahaan diperbolehkan menggunakan asumsi akan adanya penerimaaan yang belum good fund. Lebih lanjut perilaku manajamen ini bermetamoforsis menjadi financial fraud (Marai dan Pavlovic, 2013). Mendeteksi adanya pengkondisian akan earning suatu korporasi menjadi sangat penting dewasa ini, seperti kutipan berikut :

"Indeed, today's financial reports are more difficult to understand than ever. They're riddled with jargon that's hard to fathom and numbers that don't track. They're muddled, with inconsistent categories, vague entries, and hidden adjusment that disguise how much various estimates change a company's earnings from quarter to quarter, says Donn Vickrey, a former accounting professor and co-founder of Camelback Research Alliance., a Scottsdale (Ariz) firm hired by institutional investors to detect inflated earnings " (The Fuzzy Numbers Business Week, 4 Oktober 2004 Halaman 80).

Dechow dan Skinner (2000) mengutarakan pandangan mereka bagaimana praktik akuntansi yang menyimpang dengan yang memenuhi ketentuan standar akuntansi, mereka mengatakan yang membedakan adalah kecenderungan (niat atau hasrat) dari eksekutif perusahaan yang membuat laporan akuntansi. Yaping
(2005), perlu untuk mendefinisikan ulang akan pengkondisian earnings. Seperti earnings management adalah pengkondisian earnings sesuai ketentuan standar akuntansi. Creative accounting pengkondisian earnings dikarenakan tidak ada ketentuan di standar akuntansi oleh karena itu menggunakan prinsip-prinsip perhitungan dan pencatatan diluar regulasi standar, yang dapat dipertanggung jawabkan obyektifitasnya. Dan earnings fraud adalah pengkondisian earnings diluar penjelasan diatas.

Perols dan Lougee (2011) menyatakan fraud memiliki obyek yang sama dengan earnings management, namun memiliki perbedaan dimana earnings management berada dalam koridor standar akuntasi, sementara fraud berada diluar koridor tersebut. Ketika perusahaan melaporkan earnings yang telah dikondisikan menaik, dengan menggunakan income-increasing Accruals, Accruals yang digunakan ini harus disesuaikan (Healy, 1985). Karenanya perusahaan yang menggunakan income increasing Accruals di tahun akan datang harus menerima konsekuensi dari penyesuaian Accruals atau melakukan fraud untuk mengatasi penyesuaian yang dibutuhkan (Dechow et al. (1996); Beniesh (1997), Lee et al. (1999)).

Baik earnings management dan financial fraud memiliki insentif yang sama. Penelitian sebelumnya mengatakan penggunaan komponen accruals terhadap earnings untuk mencapai atau melewati target prediksi analis pasar modal (Burgstahler dan Dichev, 1997); (Burgstahler dan Eames, 2006); (Amar dan Abaoub, 2010); (Dechow et al. 2000). Dengan banyaknya kebijakan akuntansi, ketika dihadapkan pada aplikasi tidak ada batasan yang jelas kebijakan yang mana dinyatakan ilegal. Karenanya penilaian akan batasan ekstrim dalam penggunaan accruals mendorong batasan standar akuntansi dan menghasilkan arah informasi keuangan yang salah. Dengan pertimbangan ini Mulford and Comiskey (2002) memberikan definisi apabila praktik ini merupakan aggressive accounting.

Batara et al. (2016) Pengukuran yang tepat dari kinerja keuangan yang telah mempertimbangkan risiko bisnis, serta dapat memengaruhi cashflow, akan menghasilkan pengukuran yang lebih utama dari perubahan nilai perusahaan. Untuk itu perlu dilakukan kajian terkait earning management pada korporasi di Indonesia. Hal ini bertujuan melihat perilaku korporasi terutama dalam menginformasikan hasil kinerja operasi mereka melalui laporan keuangan. 
Penelitian yang dilakukan Beneish (1999) dilakukan untuk menjawab ketertarikan dari analis keuangan, regulator pasar modal, para peneliti, dan praktisi dunia investasi akan earning management. Sebuah model quantitative telah diperkenalkan oleh beliau, model ini serupa dengan model "Altman Z-Score" atau "Economic Value Added", tetapi M - score di gunakan untuk membuka tabir akan eksistensi earning management. Model ini memiliki penilaian dimana korporasi yang mendapatkan skor paling tinggi (tolak ukur -2,22 ) akan di indikasikan sebagai korporasi yang melakukan earning management. Dalam studi pada The Detection of Earning Manipulation, $M-$ score, mampu mengidentifikasi sekitar tiga per-empat (3/4) dari seluruh korporasi yang telah dinyatakan terbukti melakukan earning management, serta mampu manipulasi atau prakondisi yang dilakukan dengan sebuah aktivitas keuangan tertentu. Memperhatikan adanya skandal keuangan yang terjadi di luar negeri maupun dalam negeri sebagi contoh pada Tabel 1 .

Tabel 1. Daftar 10 besar kasus manipulasi keuangan di dunia

\begin{tabular}{|c|c|c|c|c|}
\hline Korporasi & Tahun & Kasus & Sanksi & $\begin{array}{l}\text { Dampak terhadap } \\
\text { stakeholder }\end{array}$ \\
\hline $\begin{array}{l}\text { Waste } \\
\text { Management }\end{array}$ & 1998 & $\begin{array}{l}\text { Mencatatkan earning palsu } \\
\text { senilai USD 1,7 Miliar }\end{array}$ & $\begin{array}{l}\text { Stock Exchange Commite } \\
\text { mendenda Arthur Andersen USD } \\
7 \text { Juta }\end{array}$ & $\begin{array}{l}\text { Pemegang saham rugi } \\
\text { senilai USD } 457 \text { Juta dan } \\
\text { mengajukan tuntutan class } \\
\text { action }\end{array}$ \\
\hline Enron & 2001 & $\begin{array}{l}\text { Tidak mencatakan Hutang } \\
\text { yang cukup signifikan } \\
\text { dalam balance sheet, anak } \\
\text { korporasi fiktif di negara - } \\
\text { negara tax heaven }\end{array}$ & $\begin{array}{l}\text { Hukuman penjara bagi CEO, } \\
\text { Korporasi dinyatakan bangkrut, } \\
\text { KAP Arthur Andersen dinyatakan } \\
\text { terlibat rekayasa akuntansi }\end{array}$ & $\begin{array}{l}\text { Pemegang saham rugi USD } \\
74 \text { Miliar, ribuan pegawai } \\
\text { dan investor kehilangan } \\
\text { fasilitas pensiun dan } \\
\text { pekerjaan }\end{array}$ \\
\hline WorldCom & 2002 & $\begin{array}{l}\text { Menaikkan nilai asset } \\
\text { sebesar USD } 11 \text { Miliar }\end{array}$ & $\begin{array}{l}\text { Pemecatan Direktur Keuangan, } \\
\text { Korporasi dinyatakan bangkrut, } \\
\text { Direktur Utama dituntut } 25 \text { Tahun } \\
\text { penjara }\end{array}$ & $\begin{array}{l}30.000 \text { karyawan hilang } \\
\text { pekerjaan, Investor } \\
\text { mengalami kerugian total } \\
\text { USD } 180 \text { Miliar }\end{array}$ \\
\hline Tyco & 2002 & $\begin{array}{l}\text { Direktur Utama dan Direktur } \\
\text { Keuangan mencuri USD } 150 \\
\text { Juta \& merekayasa kenaikan } \\
\text { pendapatan senilai USD } 500 \\
\text { Juta }\end{array}$ & $\begin{array}{l}\text { Direktur Keuangan dituntut 8-25 } \\
\text { tahun penjara }\end{array}$ & $\begin{array}{l}\text { Pemegang saham rugi } \\
\text { senilai USD } 2.92 \text { Miliar } \\
\text { dan mengajukan tuntutan } \\
\text { class action }\end{array}$ \\
\hline HealthSouth & 2003 & $\begin{array}{l}\text { Merekayasa kenaikan } \\
\text { earning sebesar USD 1,4 } \\
\text { Miliar untuk memenuhi } \\
\text { ekspektasi pemegang saham }\end{array}$ & $\begin{array}{l}\text { Direktur Utama di tuntut terkait } \\
36 \text { rekening fraud }\end{array}$ & $\begin{array}{l}\text { Pemegang saham rugi } \\
\text { senilai USD } 2.8 \text { Miliar dan } \\
\text { mengajukan tuntutan class } \\
\text { action }\end{array}$ \\
\hline $\begin{array}{l}\text { Freddie } \\
\text { Mac }\end{array}$ & 2003 & $\begin{array}{l}\text { Earning USD } 5 \text { Miliar tidak } \\
\text { dilaporkan }\end{array}$ & $\begin{array}{l}\text { Denda USD. } 125 \text { juta bagi } \\
\text { Komisari, Direktur utama ,dan } \\
\text { Direktur Keuangan }\end{array}$ & $\begin{array}{l}\text { Denda USD } 125 \text { Juta } \\
\text { namun hanya membayar } \\
\text { USD } 50 \text { Juta }\end{array}$ \\
\hline $\begin{array}{l}\text { American } \\
\text { International } \\
\text { Group }\end{array}$ & 2005 & $\begin{array}{l}\text { Mencatatkan pinjaman } \\
\text { sebagai pendapatan, } \\
\text { merekayasa kenaikan harga } \\
\text { saham di bursa }\end{array}$ & $\begin{array}{l}\text { Membayar denda kepada Stock } \\
\text { Exchange Committe senilai USD } \\
10 \text { Juta (2003) dan USD 1,64 } \\
\text { Miliar (2006) }\end{array}$ & $\begin{array}{l}\text { Membayar Lousinan } \\
\text { pension fund USD } 115 \\
\text { Juta dan membayar Ohio } \\
\text { Pension funds sebesar USD } \\
725 \text { Juta }\end{array}$ \\
\hline $\begin{array}{l}\text { Lehman } \\
\text { Brothers }\end{array}$ & 2008 & $\begin{array}{l}\text { Mencatatkan pinjaman } \\
\text { USD } 50 \text { Miliar sebagai } \\
\text { pendapatan }\end{array}$ & Dinyatakan bangkrut & $\begin{array}{l}\text { Hutang USD } 619 \text { Miliar } \\
\text { dan berkontribusi terhadap } \\
\text { hilangnya USD } 10 \text { Trilliun } \\
\text { kapitalisasi pasar }\end{array}$ \\
\hline $\begin{array}{l}\text { Bernie } \\
\text { Madoff }\end{array}$ & 2008 & Skema Ponzi & $\begin{array}{l}\text { Tuntutan } 150 \text { tahun penjara dan } \\
\text { USD } 170 \text { Miliar Denda, terhadap } \\
\text { direktur utama dan akuntan }\end{array}$ & $\begin{array}{l}\text { Kerugian investor USD } \\
68,4 \text { Miliar }\end{array}$ \\
\hline Satyam & 2009 & $\begin{array}{l}\text { Rekayasa pendapatan USD } \\
\text { 1,5 Miliar }\end{array}$ & $\begin{array}{l}\text { Direktur Utama dituntut namun } \\
\text { lolos karena FBI gagal karena } \\
\text { tuntutan dilakukan melewati } \\
\text { batas waktuyang ditentukan }\end{array}$ & $\begin{array}{l}\text { Direktur utama dipecat dan } \\
\text { didenda sementara satyam } \\
\text { diambil alih Mahindra } \\
\text { Group }\end{array}$ \\
\hline
\end{tabular}


Di Indonesia sendiri pemerintah dan regulator telah menindak korporasi yang memanipulasi laporan keuangan seperti yang di informasikan pada Tabel 2 . Dengan mempertimbangkan adanya skandal keuangan baik yang terjadi di luar negeri maupun di dalam negeri, serta telah menimbulkan kerugian materil dan imateril yang sangat signifikan. Sangat diperlukan untuk menguji M-score dalam mendeteksi earning management serta implikasinya pada earning korporasi di masa depan dengan menggunakan sampel dari dalam negeri. Oleh sebeb itu, tujuan penelitian ini adalah mengaplikasikan M-Score untuk mengidentifikasi terjadinya earning management pada korporasi di Indonesia. Di samping itu, bertujuan menganalisis kondisi expected future earning dari kelompok korporasi yang di informasikan terindikasi melakukan earning management.

\section{METODE PENELITIAN}

Penelitian ini merupakan penelitian kuantitatif yang menggambarkan suatu fakta atau fenomena secara statistik dan mengambarkan hubungan antara fenomena tersebut dengan menggunakan model matematis. Penelitian dilakukan dengan menggunakan pendekatan deskriptif dan pendekatan ekonometrik. Hubungan antar variabel dalam penelitian ini adalah hubungan sebab akibat dimana laporan keuangan yang terdeteksi earning management, cashflow, dan accruals merupakan variabel independen dan expected earning sebagai variabel dependen.

Tabel 2. Kasus manipulasi keuangan di Indonesia

\begin{tabular}{|c|c|c|c|}
\hline $\begin{array}{l}\text { Korporasi / } \\
\text { Industri }\end{array}$ & Tahun & Kasus & Sanksi \\
\hline $\begin{array}{l}\text { PT Katarina } \\
\text { Utama Tbk }\end{array}$ & 2012 & $\begin{array}{l}\text { menyelewengkan perolehan dana penawaran } \\
\text { umum saham perdana (IPO), penggelembungan } \\
\text { aset serta memanipulasi laporan keuangan } \\
\text { auditan } 2009\end{array}$ & $\begin{array}{l}\text { Bursa Efek Indonesia (BI) memutuskan } \\
\text { menghapus pencatatan saham }\end{array}$ \\
\hline $\begin{array}{l}\text { PT Adaro } \\
\text { Indonesia Tbk }\end{array}$ & 2013 & skandal pajak dan transfer pricing & $\begin{array}{l}\text { Belum ada solusi dan sanksi yang baku } \\
\text { untuk mengatasi masalah ini, namun } \\
\text { pemerintah membuat beberapa kebijakan } \\
\text { untuk meminimalisir masalah ini }\end{array}$ \\
\hline $\begin{array}{l}\text { PT Bumi } \\
\text { Resources Tbk }\end{array}$ & 2012 & $\begin{array}{l}\text { manipulasi dan penyelewengan laporan } \\
\text { keuangan yang dilakukan manajemen }\end{array}$ & Sangsi denda dari Otoritas Jasa Keuangan \\
\hline Bakrie Group & 2010 & $\begin{array}{l}\text { manipulasi informasi yang dilakukan oleh } \\
\text { manajemen terkait adanya dana selisih yang } \\
\text { cukup besar dalam penempatan investasi tiga } \\
\text { emiten }\end{array}$ & Sangsi denda dari Otoritas Jasa Keuangan \\
\hline $\begin{array}{l}\text { PT Kimia } \\
\text { Farma Tbk }\end{array}$ & 2002 & $\begin{array}{l}\text { mark up laba bersih dalam laporan keuangan } \\
\text { tahun } 2001\end{array}$ & $\begin{array}{l}\text { Korporasi, masing - masing direksi serta } \\
\text { Kantor Akuntan Publik dikenakan denda } \\
\text { oleh Badan Pengawas Pasar Modal }\end{array}$ \\
\hline $\begin{array}{l}\text { PT Bank } \\
\text { Century Tbk }\end{array}$ & 2013 & $\begin{array}{l}\text { Pengalihan deposito menjadi instrumen } \\
\text { investasi tanpa seizing pemilik, instrumen } \\
\text { invetasi tersebut diduga fiktif }\end{array}$ & $\begin{array}{l}\text { Terdapat dana bantuan pemerintah melalui } \\
\text { Departemen Keuangan. Dan Pemilik Bank } \\
\text { beserta management di tuntut pidana }\end{array}$ \\
\hline $\begin{array}{l}\text { Badan Usaha } \\
\text { Milik Negara }\end{array}$ & 2013 & $\begin{array}{l}\text { Tekanan terhadap akuntan publik untuk } \\
\text { melakukan pembiaran terhadap korporasi } \\
\text { BUMN yang melakukan rekayasa pada laporan } \\
\text { keuangannya }\end{array}$ & $\begin{array}{l}\text { Belum adanya mekanisme sanksi yang jelas } \\
\text { untuk BUMN khususnya yang status masih } \\
\text { tertutup. Namun, khusus yang terbuka dapat } \\
\text { menggunakan mekanisme ketentuan pasar } \\
\text { Modal }\end{array}$ \\
\hline $\begin{array}{l}\text { Sektor Per- } \\
\text { tambangan } \\
\text { Non - Migas }\end{array}$ & 2012 & skandal pajak dan transfer pricing & $\begin{array}{l}\text { Belum ada solusi dan sanksi yang baku } \\
\text { untuk mengatasi masalah ini, namun } \\
\text { pemerintah membuat beberapa kebijakan } \\
\text { untuk meminimalisir masalah ini }\end{array}$ \\
\hline
\end{tabular}


Penelitian ini menggunakan data sekunder yang berasal dari laporan keuangan tahunan yang telah diaudit dari 42 sampel korporasi yang terdaftar di Bursa Efek Indonesia. dengan melakukan seleksi terlebih dahulu terkait indikasi, laporan atau proses investigasi terkait adanya earning management mulai tahun buku 2009 sampai dengan tahun 2015. Korporasi tersebut adalah Adhi Karya, Aneka Tambang, Garuda Indonesia, Wijaya Karya, Wijaya Karya Beton, Waskita Karya, Timah, Telkom, Semen Indonesia, Bukit Asam, Perusahaan Gas Negara, Pembangunan Perumahan, Kimia Farma, Jasa Marga, Indofarma, Adaro Energy, ATPK Resources, Baramulti Suksessarana, Bakrie \& Brothers, Energi Mega Persada, Golden Eagle Energy, Harum Energy, Indo Tambangraya Megah, Perdana Karya Perkasa, Petrosea, Resources Alam indonesia, Toba Bara Sejahtera, Semen Baturaja, Bumi Resources, Darma Henwa, Mitrabara Adiperdana, Atlas Resources, Bakrie Sumatera P, Bayan Resources, Bakrie Telecom, Bakrieland Development, Berau Coal Energy, Bumi Resources Minerals, Visi Media Asia, Krakatau Steel, Golden Energy Mines, dan Samindo Resources.

Objek penelitian yang terdiri dari 42 korporasi kurun waktu mulai dari tahun 2009 sampai dengan tahun 2015 akan membentuk data panel. Analisa regresi dengan menggunakan data panel dikenal dengan analisis regresi data panel. Regresi data panel merupakan pengembangan dari regresi linier dengan metode OLS yang memiliki kekhususan dari segi jenis data dan tujuan analisisnya. Dari segi jenis data, regresi data panel memiliki karakteristik (jenis) data cross section dan time series. Sifat cross section data ditunjukkan oleh data yang terdiri lebih dari satu entitas (individu), sedangkan sifat time series ditunjukkan oleh setiap individu memiliki lebih dari satu pengamatan waktu (periode).

Dilihat dari tujuan analisis data, data panel berguna untuk melihat dampak ekonomis yang tidak terpisahkan antar setiap individu dalam beberapa periode, dan hal ini tidak bisa didapatkan dari penggunaan data cross section atau data time series secara terpisah. Adanya perbedaan karakteristik variabel terikat dari setiap entitas atau adanya pengaruh variabel lain di luar model yang ingin diamati pengaruhnya, dengan penggunaan regresi data panel akan efektif karena regresi linier tidak dapat melakukannya. Terdapat 2 keuntungan yang diperoleh dengan menggunakan data panel. Pertama, data panel merupakan gabungan dua data cross section dan time series mampu menyediakan data yang lebih banyak sehingga akan menghasilkan derajat kebebasan (degree of freedom) yang lebih besar. Kedua, menggabungkan informasi data dari cross section dan time series dapat mengatasi masalah yang timbul ketika ada masalah penghilangan variabel.

\section{Model Penelitian}

Penelitian ini menggunakan dua buah model yang, pertama adalah M-score yang bertujuan mendeteksi earning management Beneish, Lee dan Nichols (2013) dengan model sebagai berikut (penjelasan tiap variabel pada Tabel 3):

$$
\begin{aligned}
\mathrm{M}= & -4,84+0,92(\mathrm{DSRI})+0,528(\mathrm{GMI})+0,404(\mathrm{AQI}) \\
& +0,892(\mathrm{SGI})+0,115(\mathrm{DEPI})-0,172(\mathrm{SGAI})+ \\
& 4,679(\text { Accruals })-0,327(\mathrm{LVGI})
\end{aligned}
$$

Yang kedua adalah model regresi berasal dari modifikasi dari model regresi Beneish et al. (2013) yang berguna untuk menguji hubungan antar fenomena atau fakta. Model ini dimodifikasi dengan menambah varibelvariabel dummy (BUMN, MINING, BUMNMINING, $\mathrm{X}$, SPMClassict, USD) dengan tujuan dapat mengidentifikasi kondisi expected future earning kelompok-kelompok korporasi yang menjadi sampel penelitian dengan model sebagai berikut :

\section{EARNt $+1=\mathrm{a} 0+\mathrm{a} 1 \mathrm{CFOt}+\mathrm{a} 2$ Accrualst $+\mathrm{a} 3 \mathrm{ACCPOSt}$ + a4ACCNEG $\mathrm{t}+$ a5(ACCPOSt ) $($ SPM t $)+$ a6(ACCNEGt $)($ SPMt $)+$ a7SPMt + a8BUMNt + a9MININGt + a10BUMNMININGt + a11Xt + a12SPMClassict + a13USDt + e $\mathrm{t}+1$}

Keterangan: EARNt+1 (Operating earnings before depreciation); CFOt (cash flows from operations); Accrualst (working capital); ACCPOSt (working capital accruals when positive and zero otherwise); ACCNEGt (working - capital accruals when negative and zero otherwise); SPMt (M-score rangked into decile and scaled to range from 0 (lowest $\mathrm{M}$-score) to 1 (highest M-score) - Cut off Value -1,78); SPMClassict (M-score Classic rangked into decile and scaled to range from 0 (lowest $\mathrm{M}$-score) to 1 (highest $\mathrm{M}$-score) Cut off Value -2,22); BUMN (korporasi yang merupakan bagian dari Badan Usaha Milik Negara dan listing di Bursa Efek Indonesia); MINING (korporasi pertambangan non -migas yang terdaftar di Bursa Efek Indonesia); X (Non BUMN dan Non Mining); USD (Laporan Keuangan menggunakan mata uang USD). 
Berkaca dari berbagai kasus skandal keuangan dirasakan perlu memitigasi risiko earning management yang dapat merugikan investor di dalam negeri. Untuk itu metode analisis dengan menggunakan M-score digunakan untuk mengetahui tingkat distorsi dalam informasi laporan keuangan yang telah di audit yang di peruntukkan bagi masyarakat luas sehingga tidak ada misleading information dari manajemen bagi investor atau calon investor, dalam mengambil keputusan investasi di korporasi tersebut. Berikutnya kebijakan memonitor risiko earning management ini di perlukan bagi dewan komisaris serta komite audit untuk melakukan check and balance kepada manajemen dalam menjalankan operasional korporasi yang telah di amanatkan dalam Rapat Umum Pemegang Saham. Secara ringkas kerangka pemikiran disajikan pada Gambar 1
Hipotesis merupakan jawaban sementara terhadap rumusan masalah penelitian. Hipotesis yang diajukan dalam penelitian ini adalah sebagai berikut:

H1: Cashflow From Operation berpengaruhsignifikan terhadap expected future earning korporasi

H2: Accrual berpengaruh signifikan terhadap expected future earning korporasi

H3: Accrual Positif berpengaruh signifikan terhadap expected future earning korporasi

H4: Accrual Negatif berpengaruh signifikan terhadap expected future earning korporasi

H5: Accrual Positif pada perusahaan yang terdeteksi earning management Berpengaruh signifikan terhadap expected future Earning korporasi

H6: Accrual Negatif pada perusahaan yang terdeteksi earning management Berpengaruh signifikan terhadap expected future earning korporasi

H7: Earning Management berpengaruh signifikan terhadap expected future earning korporasi

Tabel 3. Operasional variabel

\begin{tabular}{|c|c|c|}
\hline Variabel & Definisi & Manfaat \\
\hline DSRI & $\begin{array}{l}\text { Days Sales in Receiable Index } \\
\text { (Receivable t / Sales t) / (Receivable t-1 / Sales t-1) }\end{array}$ & $\begin{array}{l}\text { menangkap distorsi dalam akun receivable yang } \\
\text { dapat merupakan hasil dari revenue inflation }\end{array}$ \\
\hline GMI & $\begin{array}{l}\text { Gross Margin Index } \\
\text { Gross Margin } \mathrm{t}-1 \text { / Gross Margin } \mathrm{t} \text {, dimana Gross Margin } \\
=1 \text { - Costs Of Good Sold / Sales }\end{array}$ & $\begin{array}{l}\text { Margin yang memburuk memberikan } \\
\text { kecenderungan atau alasan korporasi } \\
\text { mengkondisikan earning }\end{array}$ \\
\hline AQI & $\begin{array}{l}\text { Asset Quality Index } \\
(1-(\mathrm{PPE} \mathrm{t}+\mathrm{CA} \mathrm{t}) / \mathrm{TA} \mathrm{t}) /(1-(\mathrm{PPE} \mathrm{t}-1+\mathrm{CA} \mathrm{t}-1) / \mathrm{TA} \\
\mathrm{t}-1) \text { dimana PPE Net, } \mathrm{CA}=\text { Current Assets dan TA }= \\
\text { Total Assets }\end{array}$ & $\begin{array}{l}\text { menangkap distorsi dalam suatu aset yang dapat } \\
\text { menghasilkan belanja modal yang berlebihan }\end{array}$ \\
\hline SGI & $\begin{array}{l}\text { Sales Growth Index } \\
\text { Sales } \mathrm{t} / \text { Sales } \mathrm{t}-1\end{array}$ & $\begin{array}{l}\text { mengelola persepsi akan pertumbuhan yang } \\
\text { berkelanjutan. dan kebutuhan akan modal } \\
\text { membeikan kecenderungan korporasi bertumbuh } \\
\text { untuk memanipulasi sales dan earning }\end{array}$ \\
\hline DEPI & $\begin{array}{l}\text { Depreciation Index } \\
\text { Depreciation Rate } \mathrm{t}-1 / \text { Depreciation Rate } \mathrm{t}, \text { Depreciation } \\
\text { Rate = Depreciation / (Depreciation + PPE) }\end{array}$ & $\begin{array}{l}\text { menangkap penurunan level depresiasi sebagai } \\
\text { bentuk pengkondisian earning }\end{array}$ \\
\hline SGAI & $\begin{array}{l}\text { Sales, General and Administrative Expenses Index } \\
\text { (SGA t / Sales t) / (SGA t-1 / Sales t-1) }\end{array}$ & $\begin{array}{l}\text { penurunan efisiensi biaya pada akun } \\
\text { administrative and marketing memberikan } \\
\text { kecenderungan korporasi mengkondisikan } \\
\text { earning }\end{array}$ \\
\hline Accruals & $\begin{array}{l}\text { (Income before extraordinary items - Cash from } \\
\text { operations) / Total assets }\end{array}$ & $\begin{array}{l}\text { menangkap accounting profit yang tidak } \\
\text { didukung oleh cash profit }\end{array}$ \\
\hline LEVI & $\begin{array}{l}\text { Leverage Index } \\
\text { Leverage } \mathrm{t} / \text { Leverage } \mathrm{t}-1 \text {, Leverage }=\text { ratio debt } \\
\text { terhadap assets }\end{array}$ & $\begin{array}{l}\text { peningkatan leverage akan memperketat batasan } \\
\text { penggunaan debt dan memberikan kecenderungan } \\
\text { untuk mengkondisikan earning }\end{array}$ \\
\hline Score & & $\begin{array}{l}\text { Tolak ukur lebih dari }-1,78 \text { terindikasi melakukan } \\
\text { earning management (2013); Tolak Ukur } \\
\text { lebih dari }-2,22 \text { terindikasi melakukan earning } \\
\text { management (1999) }\end{array}$ \\
\hline
\end{tabular}


H8: Earning Management tolak ukur klasik berpengaruh signifikan terhadap expected future earning korporasi

H9: Kelompok Badan Usaha Milik Negara (BUMN) memiliki kondisi expected future earning tertentuYang Signifikan

H10: Kelompok BUMN yang bergerak di bidang pertambangan Non-minyak dan gas memiliki kondisi expected future earning tertentu yang signifikan

H11: Kelompok korporasi pertambangan non-migas memiliki kondisi expected future earning tertentu yang signifikan.

H12: Kelompok konglomerasi atau Group Usaha memiliki kondisi expected future earning tertentu yang signifikan
H13: Laporan Keuangan menggunakan mata uang USD berpengaruh signifikan terhadap expected future earning korporasi

\section{HASIL}

Sampel korporasi yang digunakan dalam penelitian ini merupakan korporasi yang terindikasi melakukan rekayasa keuangan atau earning management. Korporasi-korporasi ini dipilih dengan kriteria adanya informasi dari dokumen jurnalistik, kajian ilmiah, sanksi regulator dan keputusan pengadilan (Tabel 4). Lebih jauh kriteria yang yang di gunakan dalam penelitian termasuk yang masih dalam "proses investigasi" serta berupa "dugaan".

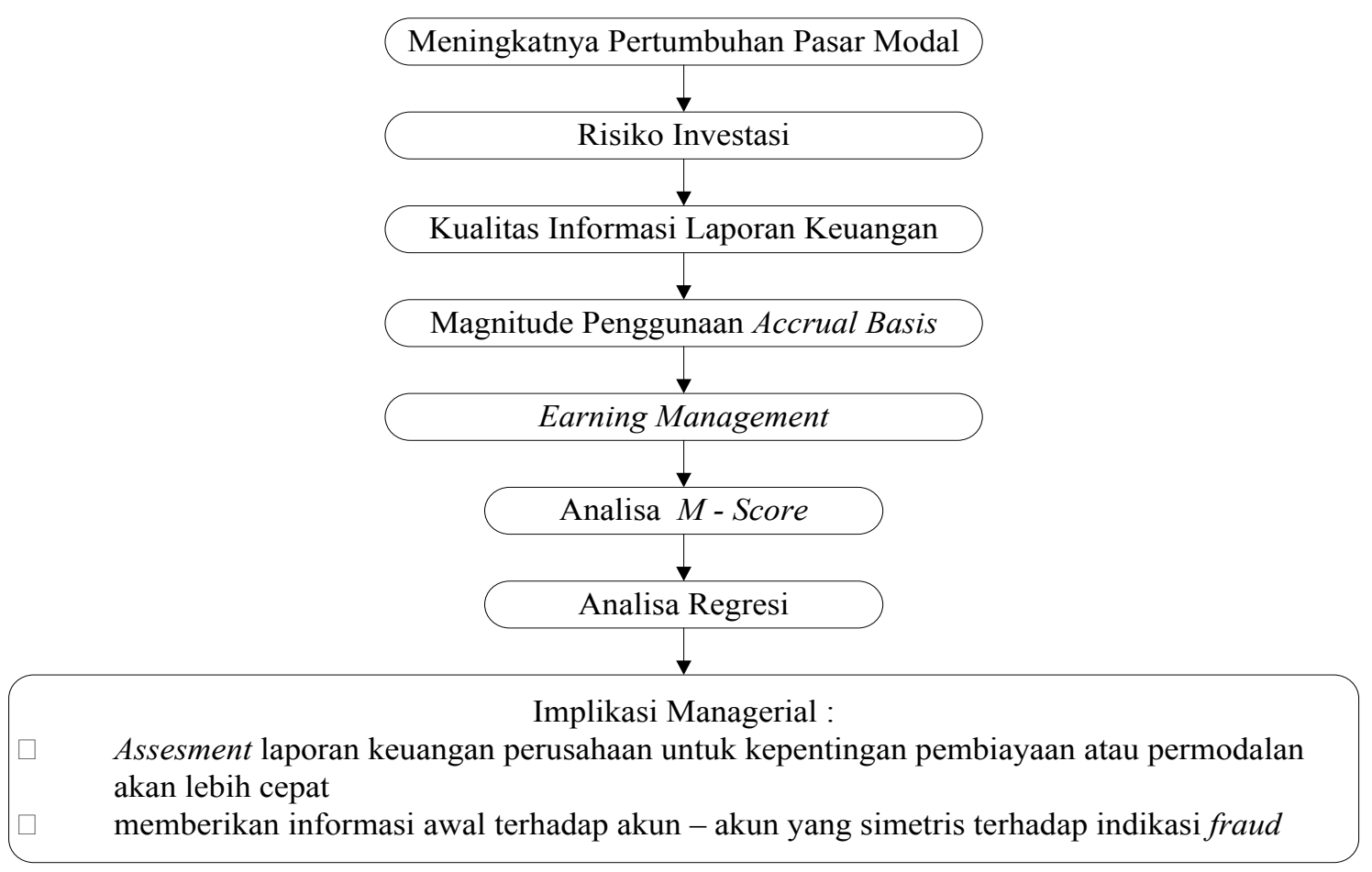

Gambar 1. Kerangka pemikiran penelitian

Tabel 4. Deskripsi data korporasi

\begin{tabular}{lccc}
\hline \multicolumn{1}{c}{ Kelompok korporasi } & Jumlah & SPM & SPMClassic \\
\hline BUMN & 12 & 3 & 5 \\
MINING* & 17 & 3 & 6 \\
BUMNMINING & 4 & 2 & 2 \\
X $^{* *}$ & 9 & 4 & 6 \\
Total & 42 & 12 & 19 \\
Mata Uang USD & 20 & 6 & 7 \\
\hline
\end{tabular}

Keterangan: * Kelompok korporasi pertambangan nonminyak dan gas; ** Kelompok korporasi konglomerasi 
Hasil F-hitung $=2,018$ dengan nilai signifikansi sebesar 0,066 lebih kecil dari alpha 0,10. Jika diuji secara simultan maka terdapat pengaruh dari seluruh variabel independen terhadap variabel dependen. Uji koefisien determinasi dimana Adj. $\mathrm{R}^{2}=0,199$ menunjukkan seluruh variabel independen mampu menjelaskan variabel dependen sebesar 19,9\% sedangkan sisanya dijelaskan oleh variable-variabel lain yang tidak diikutsertakan dalam model. Hasil lengkap pengujian regresi didapat hasil uji-t pada Tabel 5 .

Mengacu kepada persamaan regresi berganda diatas diketahui nilai konstanta sebesar 2,067 artinya jika seluruh variabel independen tidak ada $(X=0)$ maka EARNt+1 ada bernilai Positif sebesar 2,067. adapun persamaan model regresi sebagai berikut:

$$
\begin{aligned}
& \mathrm{EARN}_{\mathrm{t}+1}=2,067-0,056 \log \mathrm{CFO}_{\mathrm{t}}- \\
& \text { 0,103Log Accruals + 0,569AccPos } \\
& + \text { 2,221AccPost_Spm }+ \\
& \text { 2,861AccNeg_Spm } \text { t }_{t} \text { 0,417Bumn } \\
& \text { - 0,991Bumnminingt }-1,895 \mathrm{X}_{\mathrm{t}}- \\
& \text { 1,373.SpmClassic }-0,528 \mathrm{USD}
\end{aligned}
$$

Hasil dari penelitian diatas variabel yang berpengaruh signifikan adalah LogAccruals, AccPost_Spm AccNeg_Spm ${ }_{t}, X_{t}, S p m C l a s s i c_{t}$. Sementara variabel yang tidak berpengaruh signifikan adalah $\operatorname{LogCFO}_{t}$, AccPos $_{t}$, Bumn, $n_{t}$ Bumnmining, , USD.

Untuk Accruals hal ini belum sesuai dengan penelitian Beneish et al. (2013) terkait regresion of future earnings on current-period earnings component dimana semakin besar accruals maka semakin tinggi nilai expected future earning. Namun, begitu arah dari accruals yang berbanding terbalik dengan expected future earning masih sesuai dengan pandangan Tibbs (2003) dimana komponen accruals dilakukan perhitungan dalam sebuah permodelan statistik (discretionary accruals models) terdapat perbedaan yang signifikan (pada level signifikan 5\%) antara korporasi yang melakukan fraud dan yang tidak.

Accruals yang asimetris terhadap expected future earning terjadi karena varibel ini pertama tidak membedakan antara korporasi yang terindikasi earning management dimana disebut sebagai high persistence accruals, dengan korporasi yang tidak terindikasi disebut low persistence accruals Fairfield (Whisenant dan Yohn, 2002). Variabel ini masih di dominasi oleh low persistence accruals (Tabel 4) dimana menurut Allen et al. (2011) low persistence of accruals ada hubungan negatif antara accruals dengan perubahan expected future earnings serta expected future stock returns.

Hasil uji t diketahui bahwa ACCPOS_SPM mempunyai nilai signifikansi 0,010 lebih kecil dari 0,10 bahwa ACCPOS_SPM berpengaruh signifikan terhadap Expected Future Earning. Selanjutnya, koefisien regresi variabel ACCPOS_SPM sebesar 2.221 menunjukkan bahwa pengaruh variabel ACCPOS_SPM terhadap Expected Future Earning adalah Positif. Berdasarkan nilai koefisien regresi tersebut berarti jika ACCPOS SPMmengalamipeningkatan sebesar $1 \%$ maka Expected future earning juga akan mengalami Kenaikan sebesar 2,221 kali. Hal ini belum sesuai dengan penelitian Beneish et al. (2013) terkait Regresion of Future Earnings on Current-Period Earnings Component dimana semakin besar ACCPOS_SPM maka semakin rendah nilai expected future earning.

Accruals Positif dengan kondisi earning Management simetris terhadap expected future earning. Melihat kondisi accruals ini berasosiasi dengan terdeteksi nya earning management, variabel ini masuk kategori high persistence accruals, Menurut Allen et al. (2011) penggunaan accruals secara extrim menunjukkan frekuensi yang tinggi dari dampak penyesuaian accruals terhadap Expected future earnings expected future accruals, dan expected future stock return.

Hasil uji t diketahui bahwaACCNEG_SPM mempunyai nilai signifikansi 0,024 lebih kecil dari 0,10 berarti bahwaACCNEG_SPMberpengaruh signifikan terhadap expected future earning. Selanjutnya koefisien regresi variabel ACCNEG_SPM sebesar 2.861 menunjukkan bahwa pengaruh variabel ACCNEG_SPM terhadap future earning adalah Positif. Berdasarkan nilai koefisien regresi tersebut berarti jika ACCNEG_SPMt mengalami peningkatan sebesar $1 \%$ maka expected Future earning juga akan mengalami Kenaikan sebesar 2,861 kali. sesuai dengan penelitian Beneish et al. (2013) terkait regresion of future earnings on currentperiod earnings component dimana semakin besar ACCNEG_SPM maka semakin tinggi nilai expected future earning. 
Tabel 5. Hasil regresi

\begin{tabular}{|c|c|c|c|c|}
\hline & Hasil & Sig & VIF & Beneish, Lee dan Nichols (2013) \\
\hline Intercept & $2,067 * *$ & 0,038 & & $-0,024 * * *$ \\
\hline \multicolumn{5}{|l|}{ Earn $\mathrm{t}+1$} \\
\hline LogCFOt & $-0,056$ & 0,350 & 2,002 & $1,074 * * *$ \\
\hline LogACCRUALSt & $-0,103 *$ & 0,086 & 1,560 & \\
\hline ACCPOSt & 0,569 & 0,374 & 1,833 & $0,982 * * *$ \\
\hline ACCNEGt & Excluded Variabel & & & $0,282 * * *$ \\
\hline (ACCPOSt)(SPMt) & $2,221 *$ & 0,010 & 2,703 & $-0,259 *$ \\
\hline (ACCNEGt)(SPMt) & $2,861 * *$ & 0,024 & 1,481 & $0,699 * * *$ \\
\hline SPMt & Excluded Variabel & & & $0,031 * * *$ \\
\hline BUMNt & $-0,417$ & 0,495 & 1,682 & \\
\hline MININGt & Excluded Variabel & & & \\
\hline BUMNMININGt & $-0,991$ & 0,284 & 1,607 & \\
\hline $\mathrm{Xt}$ & $-1,895 * * *$ & 0,005 & 1,514 & \\
\hline SPMClassict & $-1,373 * *$ & 0,048 & 2,498 & \\
\hline USD & $-0,528$ & 0,337 & 1,654 & \\
\hline Adjusted R2 & $19,9 \%$ & & & $43,9 \%$ \\
\hline $\mathrm{N}$ & 42 & & & 41,053 \\
\hline Significant Level & $1 \% * * *$ & $5 \% * *$ & $10 \% *$ & \\
\hline Kolmogorov-Smirnov & 0,271 & & & \\
\hline Durbin Watson & 1,914 & & & \\
\hline Uji F & 0,066 & & & \\
\hline
\end{tabular}

Hasil uji t diketahui bahwa konglomerasi X mempunyai nilai signifikansi 0,005 lebih kecil dari 0,10 . Berarti konglomerasi $\mathrm{X}$ memiliki kecenderungan akan kondisi expected future earnings yang signifikan. Selanjutnya, koefisien regresi variabel X sebesar -1,895 menunjukkan bahwa group usaha $\mathrm{X}$ memiliki kondisi expected future earning lebih rendah sebesar 1,985 dibandingkan sektor lannya.

Berdasarkan hasil uji t diketahui bahwa SPMClassic mempunyai nilai signifikansi 0,048 lebih kecil dari 0,10 berarti bahwa SPMClassic berpengaruh signifikan terhadap expected future earning. Selanjutnya koefisien regresi variabel SPMClassic sebesar $-1,373$ menunjukkan bahwa pengaruh variabel SPMClassic terhadap expected future earning adalah Negatif. Berdasarkan nilai koefisien regresi tersebut berarti jika SPMClassic mengalami peningkatan sebesar 1\% maka expected future earning juga akan mengalami penurunan sebesar 1,373 kali. Hal ini sesuai dengan penelitian Beneish (1999) terkait The detection of earning manipulation.

Berdasarkan hasil penelitian maka dapat diperoleh informasi bahwa M-score (Klasik) mampu memprediksi kondisi tertentu sebuah earnings pada korporasi khsususnya di masa yang akan datang. Selanjutnya, terdapat kecenderungan dari kelompok korporasi tertentu dimana memiliki kondisi expected future earning yang kurang baik.

\section{Implikasi Manajerial}

Implikasi Teoritis

Hasil penelitian ini merupakan bukti empiris terhadap teori yang mendasari hubungan antara variabel yang digambarkan dalam model penelitian. Penelitian ini telah membuktikan bahwa hipotesis $\mathrm{H} 2, \mathrm{H} 5, \mathrm{H} 6, \mathrm{H} 8$ dan $\mathrm{H} 12$ diterima, artinya M-score telah teruji secara empiris mampu mendeteksi earning management yang dilakukan korporasi di Indonesia. lebih lanjut hasil dari penelitian ini menemukan bukti apabila konglomerasi $\mathrm{X}$ secara empiris, terhadap investasi yang dilakukan pemegang saham cenderung mengalami earning yang buruk dimasa depan.

Implikasi Praktis

Dalam pengujian statistik diatas telah terbukti apabila model untuk mendeteksi earning management yang diperkenalkan oleh Beneish (1999) telah terbukti 
secara empiris mampu memengaruhi expected future earnings suatu korporasi. Bagi Dewan Komisaris, dan Komite Audit laporan keuangan yang diajukan oleh manajemen harus dikritisi dengan cermat, untuk menghindarkan rusaknya nilai fundamental suatu korporasi yang berdampak merugikan bagi pemangku kepentingan dikarenakan informasi laporan keuangan yang tidak sesuai dengan kondisi sebenarnya. Adanya kecenderungan manajemen yang lebih mendahulukan kepentingan mereka sendiri, dapat memengaruhi keputusan yang diambil berkaitan dengan informasi laporan keuangan yang cenderung asimetris dari kondisi keuangan korporasi yang sudah berjalan. Oleh karena itu, para pemegang saham harus mendorong dewan komisaris dan komite audit untuk meningkatkan pengawasan kepada manajemen korporasi (kontrol kinerja operasi) berkaitan dengan kebijakan dalam menjalankan operasional korporasi dengan menggunakan indikator M-score yang sudah terbukti secara empiris.

Dalam menilai kelayakan investasi pada emiten yang di perdagangkan di bursa, Investor dan Manajer Investasi dapat menjadikan M-Score sebagai salah satu rasio keuangan yang memberikan informasi tambahan selain menilai menggunakan rasio penilaian kinerja konvensional. Penelitian ini telah membuktikan M-Score secara signifikan dapat menginformasikan expected future earning suatu korporasi. Dengan adanya M-score Investor dan Manajer Investasi dapat menambah data dalam mengambil keputusan investasi, serta merencanakan alokasi portofolio sesuai risk appetite yang mereka kehendaki. Dengan informasi yang diberikan M-Score diharapkan dapat membantu dalam menyeleksi emiten-emiten yang terdapat di Bursa Efek Indonesia sehingga membantu memberikan informasi akan kelayakan investasi.

Dalam menilai kelayakan pembiayaan usaha suatu korporasi, seorang analis kredit dapat menggunakan M-Score untuk membantu menggambarkan kondisi lapangan suatu jenis usaha. Dengan menggunakan M-score terhadap korporasi yang jelas terdeteksi melakukan earning management diharapkan seorang analis kredit akan lebih waspada serta melakukan pendalaman terkait kontradiksi yang telah di informasikan oleh M-Score. Dengan metode ini diharapkan lebih cepat dalam menganalisis suatu proposal pembiayaan yang akan berakibat kepada kecepatan dalam memutuskan kelayakan suatu proposal pembiayaan yang mana merupakan suatu hal yang wajib serta menjadi salah satu elemen penting dalam industri tersebut. M-score dapat digunakan untuk menilai karakter dari debitur.

Untuk melindungi para pemangku kepentingan, regulator diharapkan dapat meningkatkan pengawasan terhadap emiten-emiten di Bursa Efek Indonesia khususnya terkait kualitas informasi laporan keuangan, serta melindungi pemangku kepentingan dari dampak laporan keuangan yang tidak mencerminkan kondisi operasi usaha sebenarnya. Dalam hal ini regulator dapat menggunakan M-Score dalam kebijakan internal terkait kualitas informasi dari laporan keuangan emiten. Saat ini regulator beroperasi terhadap informasi laporan keuangan yang merugikan berdasarkan laporan masyarakat khususnya yang telah di rugikan. Dengan M-Score diharapkan regulator lebih proaktif dalam mengawasi informasi laporan keuangan yang diberikan oleh para emiten. Para pemangku kepentingan hendaknya mempertimbangkan M-score dalam menentukan kualitas sebuah usaha yang di informasikan melalui laporan keuangan, dalam menentukan keputusan yang akan di ambil, mengingat M-score telah terbukti mampu mendeteksi arah dari earning korporasi di masa akan datang.

\section{KESIMPULAN DAN SARAN}

\section{Kesimpulan}

Hasil pengujian secara statistik menunjukkan earning management (SPMClassic) yang dilakukan oleh suatu korporasi berpengaruh negatif secara signifikan terhadap earning korporasi dimasa yang akan datang. Untuk SPMClassic penemuan ini konsisten dengan kemampuan yang dimiliki M-score dalam mengidentifikasi korporasi yang terindikasi melakukan earning management khususnya di Bursa Efek Indonesia. SPM walaupun dikeluarkan dari pengujian statistik oleh sistem. Namun, dengan melihat Accpos(SPM) dan Accneg(SPM) yang positif dan signifikan. Peneliti menduga SPM akan pula memiliki hasil uji statistik yang sama dengan kedua variabel tersebut, hal ini pun konsisten dengan penelitian (Beneish, 2001; Beneish et al. 2013).

Hasil pengujian secara statistik menunjukkan konglomerasi atau group usaha dengan kode $\mathrm{X}$ secara signifikan memiliki kecenderungan future earning tertentu, hal ini sesuai dengan bagaimana 
konglomerasi ini menjalankan group usaha seperti yang di informasikan di berbagai media informasi. Temuan ini mengkonfirmasi apabila M-score mampu mengidentifikasi indikasi earning management pada kelompok konglomerasi atau group usaha tersebut yang terkenal dengan aksi korporasi dan cenderung dominan di Bursa Efek Indonesia, serta menyimpulkan informasi yang signifikan terkait kondisi future earning dari korporasi tersebut.

\section{Saran}

Untuk penelitian selanjutnya terkait pengaruh earning management terhadap future earning di Indonesia perlu untuk memperrhatikan kondisi sektor industri dan kondisi ekonomi dimana periode sampel di teliti. Di samping itu, perlu dilihat pengaruh earning management terhadap dependen variable lainnya seperti expected return atau struktur modal. Selanjutnya, perlu untuk di seleksi laporan keuangan yang berasal dari Kantor Akuntan Publik dengan kategori big four dengan yang tidak termasuk kategori tersebut dan melihat dampaknya dan perlu untuk pengembangan sebuah model yang dapat mendeteksi earning management pada korporasi keuangan.

\section{DAFTAR PUSTAKA}

Allen E, Larson C, Sloan RG. 2011. Accruals Reversal, Earnings and Stock Return. Available at SSRN: https://ssrn.com/abstract $=1480248$ or http:// dx.doi.org/10.2139/ssrn.1480248 [2 April 2013]. https://doi.org/10.2139/ssrn.1480248.

Amar AB, Abaoub E. 2010. Earnings management thresholds: the case in tunisia. Asian Academy of Management Journal of Accounting and Finance 6(2): 35-56.

Beneish MD. 1999. The detection of earning manipulation. Financial Analyst Journal No. 5 Sept 1999. https://doi.org/10.1016/S02784254(97)00023-9.

Beneish. MD. 2001. Earning management: a persepective. Managerial Finance, No. 12, 2001.

Beneish MD. 1997. Detecting GAAP violation: implications for assessing earnings management among firms with extreme financial performance. Journal of Accounting and Public Policy 16(3): 271-309. https://doi.org/10.2469/faj.v69.n2.1.
Beneish MD, Lee CMC, Nichols DC. 2013. Earnings manipulation and expected returns. Financial Analyst Journal No. 2, 2013

Burgstahler D, Dichev I. 1997. Earnings management to avoid earnings decreases and losses. Journal of Accounting and Economics 24 (1): 99-126. https://doi.org/10.1016/S0165-4101(97)000177.

Burgstahler D, Eames M. 2006. Management of earnings and analysts' forecasts to achieve zero and small positive earnings surprises. Journal of Business Finance \& Accounting 33(56): 633-652. https://doi.org/10.1111/j.14685957.2006.00630.x.

Dechow PM, Sloan,RG, Sweeney AP. 1996. Causes and consequences of earnings manipulation: an analysis of firms subject to enforcement actions by the SEC. Contemporary Accounting Research 13(1): 1-36.

Dechow PM, Skinner DJ. 2000. Earnings management: reconciling the views of accounting academic, practitioners, and regulators. Accounting Horizons 14(2): 335.

Healy PM. 1985. The effect of bonus schemes on accounting decisions. Journal of Accounting and Economics 13(4): 85-107.

Lee TA, Ingram, RW, Howard TP. 1999. The difference between earnings and operating cash flow as an indicator of financial reporting fraud. Contemporary Accounting Research 16(4): 749-786.

Marai A, Pavlovic V. 2013. Earnings management vs financial reporting fraud- key features for distinguishing. Facta Universitatis Series: Economic and Organization 10: 39-47.

Mulford CW, Comiskey EE. 2002. The Financial Numbers Game, Detecting Creative Accounting Practices. New York: John Wiley \& Sons, Inc.

Perols LJ, Lougee BA. 2011. The relation between earnings management and financial statement fraud. Advances in Accounting 27(1): 39-53.

Stiglitz JE. 2003. Dekade Keserakahan: Era,,90-an dan Awal Mula Petaka Ekonomi Dunia. Jakarta: Marjin Kiri.

Tibbs SL. 2003. The ability of earning management models to detect and predict public discovery of accounting - fraud [disertasi]. Tennessee: University of Tennessee.

Yaping N. 2005. The theoretical framework of earnings management la structure théorique du management des revenues. Canadian Social Science 1(3): 32-38. 